UDC 384.48

JEL L 83; Q 13

\title{
PROSPECTIVE DIRECTIONS OF GREEN TOURISM DEVELOPMENT IN UKRAINE
}

\author{
S. Buhil, PhD \\ ORCID ID: 0000-0003-4863-5235 \\ Ivan Franko National University of Lviv \\ V. Riabets \\ ORCID ID: 0000-0003-1928-8449 \\ R. Dudiak, PhD \\ ORCID ID: 0000-0001-7934-8234 \\ Lviv National Agrarian University
}

https://doi.org/10.31734/economics2019.26.151

Бугіль С., Рябець В., Дудяк Р. Перспективні напрями розвитку зеленого туризму в Україні

Підприємництво у сфері сільського зеленого туризму чинить локальний позитивний вплив на сільську територію і сільську громаду, у межах якої воно здійснюється, та сприяє:

- зниженню рівня безробіття на сільських територіях;

- диверсифікації економічної діяльності і розвитку інших галузей (промисли, ремесла, торгівля, будівництво);

- збереженню й розвитку історико-культурної спадщини села як джерела туристичної атракційності території;

- розвитку інфраструктури сільських територій;

- зростанню активності членів сільської громади та посиленню взаємодії з органами місцевого самоврядування.

Статистична інформація свідчить, що розвиток підприємництва у вказаній сфері на території України відбувається досить нерівномірно, що зумовлено природно-кліматичними умовами, наявністю історико-культурних об'єктів та збереженням національних самобутніх традицій.

Основною перешкодою в розвитку сільського зеленого туризму є неврегульоване законодавство та відсутність нормативно-правової бази, на яку б опирався саме цей вид туризму. Основним законодавчим документом, який координує і регламентує роботу в цій сфері, є Закон України «Про особисте селянське господарство», в якому зазначено, що діяльність, пов'язана з веденням особистого селянського господарства (а сільський зелений туризм $\epsilon$ структурним елементом останнього), не належить до підприємницької.

Позитивним чинником у розвитку українського агротуристичного ринку є те, що він будується децентралізовано практично без участі центральних структур. Це дає змогу розвивати такий вид бізнесу, враховуючи потреби й проблеми самого сільського населення.

Крім того, позитивну роль у становленні й розвитку сільського туризму в Україні відіграє досить високий рівень безробіття в сільській місцевості - 49\% від загальної кількості зареєстрованих безробітних у 2018 р., - який змушує населення самостійно вирішувати проблеми власної зайнятості через розвиток цього виду туризму.

Ключові слова: сільський туризм, екологічний туризм, агрооселі, туристичні ресурси.

Buhil S., Riabets V., Dudiak R. Perspective directions of green tourism development in Ukraine

Entrepreneurship in the field of rural green tourism has a local positive impact on the rural territory and the rural community, within which it is implemented and it supports:

- reduction of unemployment on rural areas;

- diversification of economic activity and development of other industries (crafts, trade, construction);

- preservation and development of the historical and cultural heritage of the village as a source of tourist attractiveness of the territory;

- development of rural infrastructure;

- increased activity of rural community members and increased interaction with local governments.

Statistics show that development of entrepreneurship in this area in Ukraine is quite uneven, due to natural and climatic conditions, presence of historical and cultural sites, and preservation of national original traditions.

It is woth noting that unregulated legislation and the lack of legal framework in the field is the main obstacle in the development of rural green tourism. The main legislative document that coordinates and regulates work in this area is the 
Law of Ukraine «On Personal Farming», which declares that activities, related to the management of private farms (and rural green tourism is a structural element of the latter), does not refer to business.

A positive factor in the development of the Ukrainian agritourism market is that it is built in a decentralized manner, i.e.with little or no involvement of central structures. It enables development of this type of business, taking into account the needs and problems of rural population.

In addition, a rather high level of rural unemployment is a positive effect for establishment and development of rural tourism in Ukraine (49\% of the total number of registered unemployed in 2018), which forces the population to solve their own employment problems independently by developing that type of tourism.

Key words: rural tourism, ecological tourism, agro-settlements, tourist resources.

Problem setting. In the recent years, green tourism has become a new world tourism trend, due to the deterioration of the environmental situation in large cities, promotion of healthy lifestyles, desire to strengthen the spiritual and physical conditions of man. The tradition of rural green tourism came to Ukraine from Europe. Green tourism is a very promising destination for our country. This is facilitated by the recreational opportunities of the territory of the country and the considerable number of original villages, where national traditions and folklore are preserved. Green tourism is capable to solve the problems of employment of rural population, rational use of nature and environment, development of territories and other branches of economy of Ukraine $[1 ; 4 ; 5]$.

The strategic goal of green tourism developing in Ukraine is to create a product that is competitive on the world market, able to maximally meet the tourist needs of the country population, to ensure complex development of territories and their socio-economic interests, while maintaining ecological balance, historical and cultural heritage.

Analysis of the recent researches and publications. The problems of studying and defining the role and importance of rural tourism in the composition of domestic tourism, and the place of the state in its regulation have been considerably concerned in the scientific works by such scientists as O. Beidik, E. Bohdanova, I. Hrishova, A. Dubodelov, Y. Zinko, V. Kafarsky, S. Kosenko, M. Kostrytsia, S. Melnichenko and others. However, a number of important problems of sustainable and efficient development of green tourism have not been yet properly addressed. Further research needs shaping of an effective strategy for the development of rural green tourism at the regional and state levels, improvement of legislation in the field of standardization, certification, labeling of "green" services, categorization of subjects of the tourist services market, as well as the development of an effective mechanism of economic relations between tourism enterprises and state and local authorities.
Task setting. The purpose of the article is to study the nature, analysis of current problems and development of perspective directions of green tourism as part of the tourism industry of Ukraine.

Main results. Entrepreneurship in the field of rural green tourism has a local positive impact on the rural territory and the rural community, within which it is implemented and it supports:

- reduction of unemployment in rural areas;

- diversification of economic activity and development of other industries (crafts, trade, construction);

- preservation and development of the historical and cultural heritage of the village as a source of tourist attractiveness of the territory;

- development of rural infrastructure;

- increased activity of members of the rural community and increased interaction with local governments [6].

The subject of rural green tourism business is represented by agro-settlements. Agrooselia is a peasant's own house, which is used for personal residence and his/her family members, as well as for his/her use (overnight) for tourism. In the recent years, there has been a gradual increase of both the number of agro-settlements and the number of tourists, who have visited them, and of course, the incomes of the owners from that type of services. Thus, comparing to 2012, in 2018, the number of persons, placed in agro-villages, increased by $62,8 \%$. At the same time, the number of green tourism estates increased at almost the same rate. It should be noted that in 2018, there were 377 agro-settlements, operating in Ukraine, with a total area of $49425.3 \mathrm{~m}^{2}$ [2].

Statistics show that development of entrepreneurship in this area in Ukraine is quite uneven, due to natural and climatic conditions, presence of historical and cultural sites, and preservation of national original traditions. The majority of agrosettlements of Ukraine is concentrated in the Carpathian region (more than 93\%), of which $81.17 \%$ are natural entrepreneurs, who provide services of rural green tourism, registered in Ivano- 
Frankivsk region, $4.24 \%$ - in Lviv region, $3.71 \%-$ in Chernivtsi region [2].

Estimating the number of tourists, who have used the services of rural green tourism market in 2017 by regions of Ukraine, Ivano-Frankivsk region remains the undisputed leader $(66,73 \%$ of the total tourist volume), the second place is taken by Chernivtsi region $(8,45 \%)$, third - Ternopil region $(4,95 \%)$, more than $3 \%$ of tourists visited Khmelnytskyi, Volyn and Lviv regions.

In Ukraine, the Union for Promoting Rural Green Tourism in Ukraine (hereinafter - the Union) has initiated the promotion of rural green tourism development ideas. At its initiative, NWT units have been established and are operating in most regions of Ukraine. Collaborating with scientists and public authorities, the Union is involved in development of programs, related to the NWT and other important regulatory documents that govern the functioning of this type of tourism in Ukraine [3].

The Union also marks the estates for compliance with the requirements of the environmental standard, and monitors the standards of operation of the farm; quality of food; rational use of water, electricity and fuel; restrictions on the use of household chemicals; quality of tourist information; support for folk traditions; quality of transport.

Activation and spread of rural green tourism in Ukraine cannot be ensured without solving the following key problems:

- lack of a clear strategy for development of rural green tourism at the regional and national levels;

- lack of clear programs of development of rural green tourism in the communities and their consideration in the plans of socio-economic development of the territory;

- imperfect current legislation in the field of standardization, certification, marking of "green" services, categorization of subjects of the tourist services market;

- unsatisfactory state of social infrastructure and technical communications (heat, water supply, availability of social facilities, lack of settlement of villages, transport networks, etc.);

- poor living standards of rural population, which reduce the potential attractiveness for domestic and foreign tourists;

- low level of information and marketing support of green tourism.

It is woth noting that unregulated legislation and the lack of legal framework of tourism is the main obstacle in development of rural green tourism. The main legislative document that coordinates and regulates work in this area is the Law of Ukraine «On
Personal Farming», which declares that activities, related to management of the private farm (and rural green tourism is a structural element of the latter), do not refer to entrepreneurial ones.

Lack of a system of stimulating green tourism, in particular, the lack of cheap loans that can be used for the modernization of tourist facilities is another restraint for green tourism development.

A positive factor in the development of the Ukrainian agritourism market is that it is built in a decentralized manner, i.e. with little or no involvement of central structures. This enables development of this type of business, taking into account the needs and problems of the rural population.

In addition, a rather high level of rural unemployment is a positive role in establishment and development of rural tourism in Ukraine ( $49 \%$ of the total number of registered unemployed in 2018), which forces the population to solve their own employment problems independently by developing this type of tourism.

The most promising area includes the Carpathian region and the Crimea. Even the State Committee for Statistics does not know the excect number of green tourism objects in the country, because no one officially counts them. According to the profile union, there are approximately 950 of them, although at least 1 million homes, out of 6-7 million rural households, can potentially receive tourists. Thus, rural tourism is an important factor for a steady dynamic increase in budget revenues, activation of development of many sectors of the economy (transport, trade, communications, construction, agriculture, etc.).

The authors of the article consider the rural green tourism in Ukraine, at the expense of preserving the ethnographic identity, should become a national industy.

First, it gives impetus to the revival and development of traditional culture: folk architecture, arts, crafts - everything that makes up the local color, and that, along with the natural and recreational factors, is no less attractive to tourists.

Secondly, residents of urban areas with mass culture have the opportunity to learn about Ukrainian traditions through rural holidays.

Third, the ethnoculture of the village represents Ukraine to the world and attracts foreign tourists. Therefore, as a prerequisite for the successful development of recreation in rural ethnographic areas, it is necessary to consider formation of the ideology of revival and development of the entire spectrum of traditional culture, from the forms of economic 
activities to the spiritual sphere, which will act as favorable factors for individual recreation in ethnographic regions of Ukraine.

Categorization of green estates is an important issue for the further development of green tourism in Ukraine. Categorization of private estates will provide: transparency of the offer for the client; quality control of the tourist product; the variety of the supplied tourist services and the difference in cost.

Introduction of categorization of accommodation facilities (facilities, where they regularly or occasionally provide accommodation services for overnight stays) should be another step to stimulate rural green tourism development in rural areas, and thus, to provide additional income for rural residents, improve employment situation. At the same time, it is also an incentive to preserve the environmentally friendly environment, which will be an essential factor for increasing tourism activity on rural areas, in particular, increasing the number of foreign consumers of rural tourist services in Ukraine, and the key to marketing success.

In order to realize the potential of green tourism successfully, it is also worth paying attention to the following problems:

- implementation of measures to support and promote green tourism at the domestic and foreign tourism markets;

- provision of organizational and material support from the state for a new type of rural services, i.e. rural green tourism and agritourism.

Therefore, for the further development of green tourism in Ukraine it is necessary:

- to invite owners of green estates to participate in a voluntary categorization program that do not participate in or fail;

- to establish and implement mechanisms of exchange of the experience in the field of "green" tourism between the regions of Ukraine and countries of the world;

- conduct workshops, particularly classes, trainings, all kinds of lessons for the owners of "green" estates, to activate their activities;

- actively use the Internet resource and social networks to display information, directly related to green tourism;

- involve bloggers and media representatives to development of green tourism, which will publicly reflect certain activities in this activity, which will enhance the image of the region.
Conclusions. Summarizing results of the study, it is possible to identify the following main areas of activity, which will increase the demand at the market of tourist services, and improve the quality of tourism product in rural green tourism.

1. Development and implementation of regional projects, aimed at improving of rural development, reforming of transport infrastructure, restoring of the work of local cultural institutions.

2. Implementation of the policy of regulation of rural green tourism development at the national and regional levels.

3. Conduction of forums, conferences, thematic exhibitions in order to promote recreation in the countryside.

4. Development of regulations on standardization of services in the field of rural green tourism, which will meet the current standards of the European model.

5. Organization of training of future specialists for the market of rural green tourism services and regulation of the number of their recruitment in higher education institutions on the basis of the state order in the targeted destinations of the regions.

6. Establishment of a system of national statistics for monitoring of regional and state programs for development of rural green tourism.

\section{References}

European Federation of Farm and Rural Tourism (EUROGITES). URL: https://www.eurogites.org/ (Last accessed: 15.06. 2019). (in Ukrainian).

2. Official site of the State Statistics Service of Ukraine. URL: http://www.ukrstat.gov.ua/ (Last accessed: 18.06. 2019). (in Ukrainian).

3. The Union of Rural Green Tourism of Ukraine. URL: https://www.greentour.com.ua/history (Last accessed: 15.06. 2019). (in Ukrainian).

4. Tourist Association of Ukraine. URL: http://www.tau.org.ua/ (Last accessed: 16.06. 2019). (in Ukrainian).

5. Ukrainian Association of International Tourism. URL: http://www.uamt.org.ua (Last accessed: 14.06. 2019). (in Ukrainian).

6. Yashchuk A. R. Prospects for development of rural green tourism in Ukraine. Proceedings of the IV AllUkrainian Scientific and Practical Conference "Modern Problems and Prospects of Economic Dynamics" (Uman, November 30 - December 1, 2017). Uman: Visa, 2017. P. 325-326. (in Ukrainian). 